\title{
Haematophagic behavior in laboratory of Lutzomyia cruzi (Mangabeira) (Diptera: Psychodidae) in relation to three mammalian blood sources in Manaus, Brazil
}

\author{
Andrezza Campos CHAGAS¹, Jansen Fernandes MEDEIROS², Sílvia Cássia Brandão JUSTINIANO², \\ Felipe Arley Costa PESSOA ${ }^{4}$
}

\begin{abstract}
The sand fly Lutzomyia cruzi is considered as one of vectors of visceral leishmaniasis in Brazil. This work examined optimum feeding age, feeding time, host preference, fecundity rates, and female blood meal volume taken by single females from a closed colony of $L$. cruzi. Mean feeding time was longer on hamsters, 6.6 minutes, than on humans, 5.7 minutes. $49.1 \%$ of the $48 \mathrm{~h}$-old flies fed on humans and $43.3 \%$ of $72 \mathrm{~h}$-old flies fed on hamsters. Of a total of 120 females, $61 \%$ fed on humans and $25 \%$ fed on hamsters. Total fecundity was significantly higher in females fed on hamster than on human or opossum. Laboratory-reared $L$. cruzi females fed earlier, more promptly, and preferably on humans than on hamsters when offered these blood-meal sources simultaneously. The blood-meal volume is higher in females fed on hamsters than other hosts (human and opossum).
\end{abstract}

\section{KEY-WORDS}

Lutzomyia cruzi, vector of visceral leishmaniasis, fecundity, blood meal volume.

\section{Comportamento hematofágico de Lutzomyia cruzi (Diptera: Psychodidae) em relação a três fontes sanguíneas de mamiferos em laboratório, Manaus, Brasil}

\begin{abstract}
RESUMO
O flebotomíneo Lutzomyia cruzi é incriminado como um dos vetores de leishmaniose visceral no Brasil. Foram estudados: a idade ótima, a preferência alimentar, os indices de fecundidade e o volume de alimentação sanguínea realizado com fêmeas de $\mathrm{L}$. cruzi colonizadas em laboratório. O tempo médio de alimentação foi maior em hamster, seguido de humano. Verificou-se que 49, $1 \%$ das fêmeas alimentaram-se em humano com $48 \mathrm{~h}$ enquanto em hamster, $43,3 \%$ alimentaram-se com $72 \mathrm{~h}$. Das 120 fêmeas observadas, $61 \%$ realizaram a alimentação em humanos e $25 \%$ em hamster. A fecundidade total foi maior nas fêmeas alimentadas em hamster, humano e mucura, respectivamente. Observou-se que fêmeas de L. cruzi colonizadas alimentam-se mais facilmente e preferencialmente em humanos do que em hamster quando ambas as fontes de alimentação são oferecidas simultaneamente. O volume da alimentação sanguínea foi maior nas fêmeas alimentadas em hamster.
\end{abstract}

\section{PALAVRAS-CHAVE}

Lutzomyia cruzi, vetor de leishmaniose visceral, fecundidade, volume sanguineo.

${ }^{1}$ Gerência de Parasitologia, Fundação de Medicina Tropical, Av. Pedro Teixeira 25, D. Pedro, 69040-000, Manaus, AM, azzapium@hotmail.com ${ }^{2}$ Laboratório de EtnoEpidemiologia, Instituto Nacional de Pesquisas da Amazônia, CP 478, 69011-970, Manaus, AM. 


\section{INTRODUCTION}

Leishmaniasis is an important public health problem in Brazil. Phlebotomine sand flies (Diptera: Psychodidae) are the vectors of leishmaniasis, as well as other vertebrate pathogens. The phlebotomine sand fly Lutzomyia longipalpis (Lutz \& Neiva) (Diptera: Psychodidae) is the primary vector of visceral leishmaniasis, currently considered the mainly Neotropical vector of this disease. Santos et al. (1998) demonstrated that Lutzomyia cruzi (Mangabeira) is a vector of visceral leishmaniasis in Corumbá and Ladário municipalities, in the Mato Grosso do Sul state, Brazil.

Despite the medical importance of L. cruzi, little is known about its biology or ecology. Justiniano et al. (2001) examined the biology of this vector under laboratory conditions, while Oliveira et al. (2003) and Santos et al. (2003) examined some ecological aspects of the species.

After the $L$. cruzi incrimination as a vector of visceral leishmaniasis, studies in laboratory colonies were necessary to know the biology of the species to corroborate that incrimination. This led to discoveries about colonization characteristics and biological cycle of L. cruzi (Justiniano et al., 2001; Brazil et al., 2002; Chagas et al., 2002). Watts et al. (2005) studied sex pheromones and the phylogeographic structure of some Lutzomyia longipalpis species complex, includind reared L. cruzi; Almeida et al. (2004) described the patterns of exochorion ornaments on eggs; Spiegel et al. described the sensilla on the terminalia of L. cruzi; Hodgkinson et al. (2002) studied the mitochondrial cytochrome B haplotypes polymorphism in $L$. cruzi and L. longipalpis populations.

New World sand fly colonies were observed under various laboratory conditions, varying factors, such as temperature, humidity, light level, and larval food sources (Sherlock \& Sherlock, 1959; Killick-Kendrick et al., 1977; Rangel et al., 1987; Luitgards-Moura et al. (2000). There are few laboratory studies addressing haematophagic behavior by sand flies using different blood meal sources, optimal feeding age, fecundity, fertility, and female blood meal volume (Ready, 1979; Benitode-Martín et al., 1994; Queiróz, 1995; Ximenes et al., 2001).

According to the review of Lehane (1991), physiological factors are mainly important in determining host choice, in the sense that once the insect has become associated with a narrow range of hosts; then specialization in its physiology will occur which may limit the range of other hosts it can exploit. This is because natural selection will ensure that all of the systems of the insect will become tuned to the exploitation of the resources of its major hosts that may restrict the insect's ability to deal with unusual situations. Several experimental studies have shown that the fecundity of blood-sucking insects depends on the host on which the insect is fed, reduced food intake or rate of digestion (Rothshild, 1975). Krinsky et al., (1952) showed that in some cases choice of the wrong host can, for physiological reasons, lead to the death of the insect by, for example, the crystals of oxyhaemoglobin that may form in the blood of a guinea-pig (Cavia sp.) can cause the rupture of the intestine of several blood-sucking insects.

Our objective is to examine how food source affects the haematophagic behavior of colonized $L$. cruzi. We examined timing of first blood meal, optimal feeding age, food source preference for hamster (Mesocricetus auratus Waterhouse) and man, and fertility, fecundity, and female blood meal volume for hamster, man and opossum (Didelphis marsupialis Linnaeus) and human.

\section{MATERIAL AND METHODS}

L. cruzi matrices were originated from the Corumbá Municipality (18059'44”S; 57037'16”W), in the Mato Grosso do Sul state, Brazil, and laboratory colonies were established using techniques described by Killick-Kendrick et al. (1977), Killick-Kendrick \& Killick-Kendrick (1991) and Justiniano et al. (2004).

\section{OPTIMAL FEEDING AGE, TIMING, AND FOOD SOURCE PREFERENCE}

Optimal feeding age is defined as the age at which the largest numbers of females of similar age females take their first blood meal. One, two, and three days after their emergence, 20 females and 20 male of sand flies were offered blood meals from two sources: hamster under Ketalar ${ }^{\circledR}$ anesthesia, and human (forearm of the author). Food sources were offered for one hour in the laboratory ( $27^{\circ} \mathrm{C}$ and $92 \%$ humidity).

\section{FECUNDITY, FERTILITY, AND BLOOD MEAL VOLUME}

We defined fecundity as the number of eggs successfully deposited plus the eggs retained in the ovaries. Fertility was defined as the number of eggs successfully deposited (Queiróz, 1995). Hamster, human, and common opossum (under Ketalar ${ }^{\circledR}$ anesthesia) were offered as haematophagic sources for $L$. cruzi females. We recorded and compared fecundity and fertility rates after the females laid eggs and died.

Blood meal volume was measured per individual female using the hemiglobinometry method (Brigel et al., 1979), where hemoglobin is converted into an erythrocyte suspension lysate by a stable complex, hemiglobincyanide (HiCN). Immediately after feeding, the gut of each female was dissected and the Malpighian tubes removed to avoid uric acid interfering with the trials.

We placed each blood-filled gut into microtubes with $600 \mu \mathrm{l}$ of Drabkin reagent (Legowski \& Boroviczeny, 1962), composed of: $1.0 \mathrm{~g}$ sodium bicarbonate $\left(\mathrm{NaHCO}_{3}\right), 0.1 \mathrm{~g}$ potassium carbonate $\left(\mathrm{K}_{2} \mathrm{CO}_{3}\right), 0.05 \mathrm{~g}$ potassium cyanide $(\mathrm{KCN}), 0.2 \mathrm{~g}$ potassium ferricyanide $\left[\mathrm{K}_{3} \mathrm{Fe}(\mathrm{CN})_{6}\right]$, and distilled water. We incubated samples at $15-23^{\circ} \mathrm{C}$ for 20 minutes and then used a 
$540 \mathrm{~nm}$ spectrophotometer to determine optical density (OD).

We constructed calibration curves for each blood-meal source (human, hamster, opossum), which determined the ODs for different known blood volumes for each host $(0.1 ; 0.2 ; 0.4$; $0.6 ; 0.8 ; 1.0 ; 2.0 ; 3.0 ; 4.0 ; 5.0 \mu \mathrm{l})$. To some samples, we were unable to accurately measure the amount of blood ingested by the female; we used the observed OD and these linear equations and then obtained a linear regression to determine ingested blood volume in these cases.

We performed four replicates of the fecundity and fertility experiments (100 total females) for each blood meal source, and analyzed the results using parametric analysis of variance (ANOVA) or non-parametric Kruskal-Wallis one-way ANOVA, depending upon whether or not the data was distributed normally (Zar, 1996).

\section{RESULTS}

\section{OPTIMAL FEEDING AGE, TIMING, AND FOOD SOURCE} PREFERENCE

Of 120 L. cruzi females offered human and hamster food sources, 61 (50.8\%) fed on human, 30 (25.0\%) on hamster, and $29(24.1 \%)$ did not take a blood meal (Table 1). The optimal feeding age for human food sources was the second day after emergence, with $49.1 \%$ (30) of the females taking a human blood meal when reaching this age. Optimal age for females feeding on hamsters was three days post-emergence, with 43.3 $\%$ (13) individuals taking a blood meal. Blood meals were longer when feeding on hamsters (mean time $=6.6 \mathrm{~min}$, range $=2.2$ 8.9), than humans (mean time $=5.7 \mathrm{~min}$, range $=2.0-13.0$ ).

\section{FECUNDITY, FERTILITY, AND BLOOD MEAL VOLUME}

Females that fed on hamster blood had significantly higher fecundity than females that fed on either humans or opossums $(\mathrm{H}=23.6 \mathrm{df}=2 \mathrm{P}<0.001$ Kruskal-Wallis). Fertility was also higher, but not significantly, in females that fed on hamster blood than those that fed on human or opossum blood $(\mathrm{F}=$ $1.96 \mathrm{df}=2 \mathrm{P}=0.14$ ANOVA). Females that fed on hamster blood also retained significantly more eggs in their ovaries than those that fed on other sources $(\mathrm{H}=18.6 \mathrm{df}=2 \mathrm{P}<0.001)$ (Table 2).

Table 1 - Optimal feeding age and length (min) of blood meal in laboratory for Lutzomyia cruzi on human and hamster food sources.

\begin{tabular}{ccccccc}
\hline \multicolumn{7}{c}{ Mlood sources } \\
\hline & $24 \mathrm{~h}$ & $48 \mathrm{~h}$ & $72 \mathrm{~h}$ & $24 \mathrm{~h}$ & $48 \mathrm{~h}$ & $72 \mathrm{~h}$ \\
\hline Mean \pm SD & $5,6 \pm 3.1$ & $6,1 \pm 2.5$ & $5,1 \pm 2.4$ & $7,5 \pm 4.4$ & $5,2 \pm 1.7$ & $7,0 \pm 5.2$ \\
\hline Minimum & 2,0 & 2,1 & 2,6 & 2,5 & 2,2 & 2,5 \\
Maximum & 10,2 & 12,7 & 12,2 & 16,0 & 7,4 & 19,0 \\
\hline Total $\odot$ ๑ & 10,0 & 30,0 & 21,0 & 8,0 & 9,0 & 13,0 \\
\hline $\mathrm{N}=120$ (Number of females), SD = Standard deviation & &
\end{tabular}

Female blood meal volume was greater when feeding on hamsters (mean volume $=1.5 \mu$ l) than on humans (mean volume $=0.7 \mu \mathrm{l})$ or opossums $($ mean volume $=1.1 \mu \mathrm{l})$. Linear regression equations for blood meal volume and optical density were as follows: hamster, $\mathrm{y}=8.47 \mathrm{x}-0.99, \mathrm{r}=0.99, \mathrm{n}=23$; opossum, $\mathrm{y}$ $=7.51 \mathrm{x}-0.93, \mathrm{r}=1$; human, $\mathrm{y}=5 \mathrm{x}-0.26, \mathrm{r}=0.98 \mathrm{n}=23$ (Figure 1).

\section{DISCUSSION}

The optimal age for $L$. cruzi to feed on humans was two days post-emergence. This is quite different from the optimal age for another human-biting leishmaniasis vector, $L$. whitmani (Antunes \& Coutinho), with an optimal age of six or seven days post-emergence (Queiróz, 1995). We found the optimal age for L. cruzi to feed on hamsters was three days post-emergence. Still, our results are slightly earlier than optimal ages for $L$. migonei (França) and L. evandroi (Costa Lima \& Antunes), four days post-emergence and L. lenti (Mangabeira), five days postemergence (Queiróz, 1995). Our results are similar to other studies in that they confirmed that phlebotomine food source preference may vary with age. Since our experiments offered equal chances to feed on either food source and as choice varied with age, perhaps food source choice is regulated by a specific mechanism, rather than being simply a question of host availability (Queiróz, 1995; Nieves \& Pimenta, 2002).

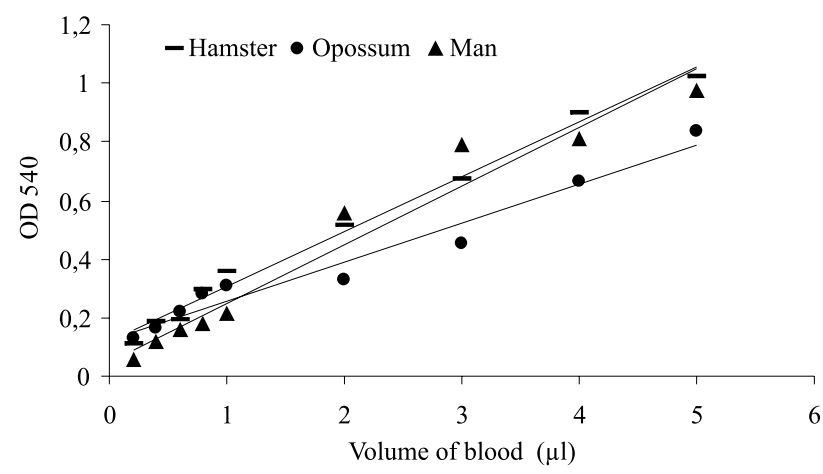

Figure 1 - Linear regression of $\mathrm{HiCN}\left(\mathrm{OD}_{540}\right)$ and blood sample from hamster $(Y=8.47 X-0.99, r=0.99, n=23)$, opossum $(Y=7.51 X-0.93, r=1$, $n=23)$, and human $(Y=5.00 X-0.26, r=0.98, n=23)$.

Table 2 - Number of eggs laid and retained in Lutzomyia cruzi females that fed on human, hamster, or opossum blood in laboratorial conditions.

\begin{tabular}{|c|c|c|c|c|c|c|}
\hline & \multicolumn{2}{|c|}{ Man } & \multicolumn{2}{|c|}{ Hamster } & \multicolumn{2}{|c|}{ Opossum } \\
\hline & Mean \pm SD & Total & Mean \pm SD & Total & Mean \pm SD & Total \\
\hline Laid eggs & $\begin{array}{c}23,9 \pm 18,4 \\
(0-73)\end{array}$ & 2309 & $\begin{array}{c}27,9 \pm 24,8 \\
(0-89)\end{array}$ & 2797 & $\begin{array}{c}27,4 \pm 23,7 \\
(0-99)\end{array}$ & 2740 \\
\hline $\begin{array}{c}\text { Retained } \\
\text { eggs }\end{array}$ & $\begin{array}{c}13,8 \pm 14,8 \\
(0-56)\end{array}$ & $1389 *$ & $\begin{array}{c}23,5 \pm 23,1 \\
(0-83)\end{array}$ & $2359^{*}$ & $\begin{array}{c}10,4 \pm 14,3 \\
(0-52)\end{array}$ & $1047^{\star}$ \\
\hline Total & & $3698 *$ & & $5156^{*}$ & & $3787^{*}$ \\
\hline
\end{tabular}

${ }^{*}$ The difference is significant $\mathrm{P}<0,001$ (Kruskal-Wallis on Way ANOVA).

$N=100$ (Number of females), $S D=$ Standard deviation 
In this study we found that $16.4 \%$ of $L$. cruzi females took a blood meal on the first day after emergence. The majority of phlebotomine females do not feed during the first 24 hours after emergence. Other studies show slightly higher levels of first-day feeding. Approximately $20 \%$ one-day old L. migonei individuals took a blood meal (Queiróz, 1995), while 30\% of Phlebotomus papatasi (Scopoli) individuals were found to feed on their first day post-emergence (Adler \& Theodor, 1927).

Mean feeding time was longer in hamster sources $(6.6 \mathrm{~min})$ than in humans $(5.7 \mathrm{~min}$ ) for $L$. cruzi. The species $L$. longipalpis was found to feed between 2-5 minutes, while $L$. sanguinaria (Fairchild \& Hertig), L. gomezi (Nitzulescu), and L. cruciata (Coquillett) spent about five minutes to complete a blood meal on a variety of hosts: humans, dogs (Canis familiaris Linnaeus), and fox (Cerdocyon thous (Linneaus)) (Sherlock \& Sherlock, 1959). Sand flies have a pool feeding mouth morphology, which may require some spending time for feeding. Females secrete anti-haemostatic salivary substances to facilitate the feeding process, in which they generate a haematoma on the skin of the host. This could explain why the majority of species do not take a blood meal on the first days after emergence, since females usually require $48 \mathrm{~h}$ to develop the ability to produce sufficient amounts of saliva (Cupp et al., 1993).

We found that $L$. cruzi preferred human blood sources $(50.8$ \%) over hamster (25.0\%). Phlebotomus perniciousus Newstead was found to prefer rabbit sources over hamster (Benito-deMártín et al., 1994), while L. lenti and L. evandroi preferred hamsters over human blood sources (Queiróz, 1995). Although L. migonei was found to bite hamsters more frequently than other offered sources, this species bit humans at the same rate as L. whitmani, which showed a strong preference for humans (Queiróz, 1995). The ability of Leishmania Ross to survive and develop during phlebotomine digestion of blood is fundamental for the successful establishment of the parasite population in the vector (Nieves \& Pimenta, 2002). When the infection rates of seven different vertebrate species were compared after experimental exposure to Leishmania braziliensis Viana and $L$. migonei, four species, including humans, had higher infection rates than the other three species (Nieves \& Pimenta, 2002). While this study showed that phlebotomine food-source preference may be important in determining infection rates, these results demonstrate that vertebrate hosts may have varying susceptibility to infection, which can also play an important role in determining regional infection rates.

We found the highest fecundity in females that fed on hamster blood, versus human or opossum blood. L. longipalpis females that fed on hamster blood, versus other mammal sources (including humans), had the highest numbers of mature oocytes (Ready, 1979). L. intermedia (Lutz \& Neiva) female egg deposition rates did not differ depending on food source, in a study that offered either hamster or mouse (Mus musculus
Linnaeus) blood (Miranda et al., 2001). Wild L. umbratilis (Ward \& Fraiha) specimens deposited the most eggs when fed on human blood, but retained more eggs when fed on opossum blood (Chagas et al., 2002).

Despite the large variability in the mean number of eggs deposited by each phlebotomine species, as well as among individuals within species, on average, individuals deposit between 20 and 30 eggs (Forattini, 1973). L. shannoni (Dyar) was found to deposit an average of 22.7 eggs and retain 24.3 (Ferro et al., 1998). In this study, L. cruzi deposited an average of 27.9 eggs and retained 23.5. These numbers are similar to those of L. longipalpis (Luitgards-Moura et al., 2000), are not surprising considering they are in the same sub-genus and share colonization characteristics.

Female blood meal volume was greater when sand flies fed on hamsters $(1.5 \mu \mathrm{l})$ than other food sources. Normal blood meal volume usually approximates an individual's total body weight (0.5-0.6 mg) (Theodor, 1936; Chaniotis, 1967). Blood meal volume is important for fecundity because it determines how many oocytes develop to maturity (Ready, 1979). For $L$. longipalpis, mature oocyte numbers are linearly related to mammalian food sources, which relates to ingested blood volume, since blood of some vertebrate species are more nutritious than others (Ready, 1979). For Culex pipiens Linnaeus, the numbers of mature oocytes depends not on blood-meal volume, but on the protein content of the blood (Bellamy \& Bracken, 1971), as some amino acids are essential for oogenesis. Colonies of sand flies are invaluable for the knowledge of insect biology, physiology, behavior, and vectorial efficiency. The knowledge of blood volume ingested by phlebotomine is important, because with this knowledge it is possible to quantify the exact quantity, for example, of Leishmania ingested in experiments of laboratorial infection (Queiróz, 1995).

\section{ACKNOWLEDGMENTS}

To the late Dr. Raul de Queiróz, adviser of the first and last two authors. His $\mathrm{PhD}$ thesis, an important source cited here, is still unpublished.

\section{LITERATURE CITED}

Adler, S.; Theodor, O. 1927. Attempts to transmit Leishmania tropica by bite: The transmission of L. tropica by Phebotomus sergpti. Annals of Tropical Medicine and Parasitology, 23: 1-18.

Almeida, D.N.; Silva, O.R.; Brazil, B.G.; Soares, M.J. 2004. Patterns of exochorion ornaments on eggs of seven South American species of Lutzomyia sand flies (Diptera: Psychodidae). Journal of Medical Entomology, 41(5): 819-25.

Bellamy, R.E.; Bracken, G.R. 1971. Quantitative aspects of ovarian development in mosquitoes. Canadian Entomologist, 103: 763773.

Benito-de-Martín, M.I.; Gracia-Salinas, M.J.; Molina-Moreno, R.; Ferrer-Dufol, M.; Lucientes-Curdi, J. 1994. Influence of the 
nature of the ingested blood on the gonotrophic parameters of Phlebotomus perniciosus under laboratory conditions. Parasite, 1(4): 409-411.

Brazil, B.G.; Teixeira, P.M.F.; Leal, C.S.; Brazil, R.P. 2002. Biology of Lutzomyia (Lutzomyia) cruzi (Mangabeira, 1938), in a laboratory colony. Entomologia y Vectores, 9(supl. 1): 64-65.

Brigel, H.; Lea, O.A.; Klowden, J.M. 1979. Hemoglobimetry as a method for measuring blood meal sizes of mosquitoes (Diptera: Culicidae). Journal of Medical Entomology, 15(3): 235-238.

Chagas, A.C.; Justiniano, S.C.B.; Medeiros, J.F.; Alencar, R.B.; Queiróz, R.G. 2002. Blood-Feeding Behaviour of Lutzomyia cruzi under laboratory conditions. Preliminary observations. Entomologia y Vectores, 9(supl. 1): 88-89.

Chaniotis, B.N. 1967. The biology of California Phlebotomus (Diptera, Psychodidae) under laboratory conditions. Journal of Medical Entomology, 4: 221-223.

Cupp, M.S.; Cupp, E.W.; Ramberg, F.B. 1993. Salivar gland apyrase in black flies (Simulium vittatum). Journal of Insect Physiology, 39: 817-821.

Ferro, C.; Cárdenas, E.; Corredor, D.; Morales, A.; Munstermann, L.E. 1998. Life cycle and fecundity analysis of Lutzomyia shannoni (Dyar) (Diptera: Psychodidae). Memórias do Instituto Oswaldo Cruz, 93(2): 195-199.

Forattini, O.P. 1973. Entomologia Médica Vol. 4. Ed. Edgard Blücher, São Paulo. 658 pp.

Hodgkinson, V.H.; Birungi, J.; Haghpanah, M.; Joshi, S.; Munstermann, L.E. 2002. Rapid identification of mitochondrial cytochrome B haplotypes by single strand conformation polymorphism in Lutzomyia longipalpis (Diptera: Psychodidae) populations. Journal of Medical Entomology, 39(4): 689-94.

Justiniano, S.C.; Chagas, A.C.; Queiróz, R.G.; Santos, S. 2001. Biology of Lutzomyia cruzi (Diptera: Psychodidae) under laboratory conditions. Revista da Sociedade Brasileira de Medicina Tropical, 34(Supl. 1): 481.

Justiniano, S.C.B.; Chagas, A.C.; Pessoa, F.A.C.; Queiróz R.G. 2004. Comparative biology of two populations of Lutzomyia umbratilis (Diptera: Psychodidae) of Central Amazonia, Brazil, under laboratory conditions. Brazilian Journal of Biology, 64(2): 227235.

Killick-Kendrick, M.; Killick-Kendrick, R. 1991. The initial establishmentnof sandfly colonies. Parasitologia, 33: 315-320.

Killick-Kendrick, R.; Leaney, A.J.; Ready, P.D. 1977. The establishment maintenance and productivity of a laboratory colony of Lutzomyia longipalpis (Diptera: Psychodidae). Journal of Medical Entomology, 13(4-5): 429-440.

Krinsky, S.; Kuchta, A.; Becla, E. 1952. Research on the nature of the noxious action of guinea-pig blood on the body louse [In Polish]. Bulletin Institute of Marine Medicine, 4: 104-107.

Legowski, S.T.; Boroviczeny, K.G.V. 1962. Exakte Hämoglobinbestimmung in der täglichen Praxis. Deutsche Medizinische Wochenschrift, 87: 1953-1960.

Lehane, M.J. 1991. Biology of blood-sucking insects. Chapman \& Hall Press, London, 288 pp.
Luitgards-Moura, J.F.; Castellón-Bermúdez, E.G.; Rosa-Freitas, M.G. 2000. Aspects related to productivity for four generations of a Lutzomyia longipalpis laboratory colony. Memórias do Instituto Oswaldo Cruz, 95(2): 251-257.

Miranda, J.C.; Machado, K.Q.; Fernandes, A.L.; Barral, A. 2001. Alimentação de Lutzomyia intermedia (LUTZ, NEIVA, 1912) em Hamster e Camundongo para a Manutenção de uma Colônia em Laboratório. Revista da Sociedade Brasileira de Medicina Tropical, 34(supl. 1): 186.

Nieves, E.; Pimenta, P.F. 2002. Influence of vertebrate blood meals on the development of Leishmania (Viannia) braziliensis and Leishmania (Leishmania) amazonensis in the sand fly Lutzomyia migonei (Diptera: Psychodidae). American Journal of Tropical Medicine and Hygiene, 67(6): 640-647.

Oliveira, A.G.; Andrade-Filho, J.D.; Falcão, A.L.; Brazil, R.P. 2003. Estudo de flebotomíneos (Diptera, Psychodidae, Phlebotominae) na zona urbana da cidade de Campo Grande, Mato Grosso do Sul, Brasil, 1999-2000. Cadernos de Saúde Pública, 19(4): 933-944.

Queiróz, R.G. 1995. Phlebotomine Sand flies of a leishmaniasis focus in Baturité, Brazil. PhD's Thesis, Department of Biology, Imperial College of Science, Technology and Medicine, University of London, Ascot, UK. 227 pp.

Rangel, E.F.; Nataly, A.S.; Wermelinger, E.D.; Barbosa, A.F. 1987. Biologia de Lutzomyia intermedia (Lutz \& Neiva, 1912) e Lutzomyia longipalpis (Lutz \& Neiva, 1912) (Diptera, Psychodidae) em condiçōes experimentais. II. Influência de fatores ambientais no comportamento das formas imaturas e adultas. Memórias do Instituto Oswaldo Cruz, 82(3): 319-323.

Ready, P.D. 1979. Factors affecting egg production of laboratorybred Lutzomyia longipalpis (Diptera: Psychodidae). Journal of Medical Entomology, 16(5): 413-423.

Rothschild, M. 1975. Recent advances in our knowledge of the Siphonaptera. Annual Review of Entomology, 20: 241-59.

Santos, O.S.; Arias, J.R.; Ribeiro, A.A.; Hoffmann, P.M.; Freitas, R.A.; Malacco, M.A.F. 1998. The incrimination of Lutzomyia (L.) cruzi as a vector of American visceral leishmaniasis. Medical and Veterinary Entomology, 12: 101-103.

Santos, S.O.; Arias, J.R.; Hoffmann, M.P.; Furlan M.B.G.; Ferreira, W.F.; Pereira. C.; Ferreira, L. 2003. The presence of Lutzomyia longipalpis in a focus of American visceral leishmaniasis where the only proven vector is Lutzomyia cruzi, Corumbá, Mato Grosso do Sul State. Revista da Sociedade Brasileira de Medicina Tropical, 36: 633-634.

Sherlock, I.A.; Sherlock, V.A. 1959. Criação e biologia, em laboratório do Phlebotomus longipalpis Lutz \& Neiva, 1912. Revista Brasileira de Biologia, 19: 97-107.

Spiegel, C.N.; Brazil, R.P.; Soares, M.J. 2000. Sensilla on the terminalia of Lutzomyia spp. (Diptera: Psychodidae) sand flies. Journal of Medical Entomology, 37(6): 860-863.

Theodor, O. 1936. On the relation of Phlebotomus papatasi to the temperature and humidity of the environment. Bulletin of Entomological Research, 27: 653-671. 
Watts, P.C.; Hamilton, J.G.; Ward, R.D.; Noyes, H.A.; Souza, N.A.; Kemp, S.J.; Feliciangeli, M.D.; Brazil, R.; Maingon, R.D. 2005. Male sex pheromones and the phylogeographic structure of the Lutzomyia longipalpis species complex (Diptera: Psychodidae) from Brazil and Venezuela. American Journal of Tropical Medicine and Hygiene, 73(4): 734-743.

Ximenes, M.F.F.; Maciel, J.C.; Jerônimo, S.M. 2001. Characteristics of the biological cycle of Lutzomyia evandroi (Costa Lima \& Antunes, 1936) (Diptera: Psychodidae) under experimental conditions. Memórias do Instituto Oswaldo Cruz, 96(6): 883886.
Zar, J. 1996. Biostatical Analysis. Third Edition, Prentice Hall International Editions, 662p.

Rcebido em 06/10/2006

Aceito em 02/02/2007 